\title{
The Relative Merit of Ruminal Undegradable Protein from Soybean Meal or Soluble Fiber from Beet Pulp to Improve Nitrogen Utilization in Dairy Cows
}

\author{
S. I. Borucki Castro, ${ }^{*}$ L. E. Phillip, ${ }^{*}$ H. Lapierre,† P. W. Jardon, $\ddagger$ and R. Berthiaume ${ }^{1}$ \\ *McGill University, Macdonald campus, Ste. Anne de Bellevue, QC, Canada H9X 3V9 \\ †Agriculture and Agri-Food Canada, Dairy and Swine Research and Development Centre, Sherbrooke QC, Canada J1M $1 Z 3$ \\ $\ddagger$ West Central, Ralston, IA 51459
}

\section{ABSTRACT}

Early lactating dairy cows were used to determine whether the replacement of solvent-extracted soybean meal [SSBM; a source of rumen-degradable protein (RDP)] with expeller soybean meal (ESBM; a source of rumen-undegradable protein), or the replacement of high-moisture shelled corn (HMSC) with beet pulp (a source of soluble fiber) would be effective in improving efficiency of $\mathrm{N}$ usage for milk production. The study was designed as a replicated $4 \times 4$ Latin square with 21-d periods. Eight multiparous Holstein cows were fed, ad libitum, the following diets, which were based on alfalfa silage and HMSC, and formulated to be isocaloric: 1) basal diet without a protein supplement (negative control diet: NC); 2) NC supplemented with solvent-extracted SBM (diet SSBM); 3) NC supplemented with expeller SBM (diet ESBM); 4) SSBM in which unmolassed dried beet pulp replaced half of the HMSC (diet SSBMBP). Compared with diet NC, protein supplementation increased intake of organic matter and dry matter. Milk and milk protein yields were lower with $\mathrm{NC}$ but this diet resulted in the greatest efficiency of $\mathrm{N}$ usage for milk production (30\% milk N/N intake). Supplementation with ESBM, a proven source of RUP, increased plasma concentrations of histidine and branched-chain amino acids, and reduced milk urea $\mathrm{N}$ concentration, but failed to improve the yields of milk or milk protein. Milk fat yield tended to decrease with RUP supplementation. Replacing part of HMSC with soluble fiber from beet pulp (SSBMBP) tended to decrease milk production compared with SSBM; the effect was due to a reduction in dry matter intake. There were no differences among diets SSBM, ESBM, or SSBMBP in urinary excretion of purine derivatives. Neither substitution of ESBM for SSBM nor partial replacement of HMSC with beet pulp altered

Received August 24, 2007.

Accepted June 12, 2008.

${ }^{1}$ Corresponding author: berthiaumer@agr.gc.ca the efficiency of $\mathrm{N}$ usage for milk production or manure $\mathrm{N}$ excretion.

Key words: expeller soybean meal, beet pulp, nitrogen efficiency, lactation performance

\section{INTRODUCTION}

In a recent review of protein feeding of dairy cows, Vandehaar and St-Pierre (2006) concluded that dairy farmers have had little incentive to feed diets that increase the efficiency of $\mathrm{N}$ usage, because the risk of underfeeding protein is more costly that the risk of protein overfeeding. However, current concerns about the impact of dairy production on the environment (Kellogg et al., 2000; MacRae and Smith, 2000) have stimulated interest in increasing the efficiency of $\mathrm{N}$ usage for milk production and reducing $\mathrm{N}$ excretion in manure. Under conditions of adequate energy intake, overfeeding protein in ruminants does not increase milk production but it results in progressive increases in manure N excretion (Wu and Satter, 2000; Kebreab et al., 2001; Olmos Colmenero and Broderick, 2006a,b). Manure N excretion leads to increases in atmospheric ammonia and $\mathrm{N}$ oxide, and emission of these gases contributes to ecological damage and climate change (Vandehaar and St-Pierre, 2006).

Strategies to increase the efficiency of $\mathrm{N}$ usage and reduce environmental pollution due to dairy farming include reducing rumen degradability of protein, supplying RUP in the diet (Ipharraguerre and Clark, 2005), or increasing the availability of fermentable energy to enhance microbial capture of RDP in the rumen (Børsting et al., 2003; Hristov and Jouany, 2005). Research has shown that dietary supplementation with expeller soybean meal (SBM), a proven source of RUP (Borucki Castro et al., 2007), results in a mere 3\% increase in milk production by dairy cows; however, in these studies, no measurements were made of manure $\mathrm{N}$ excretion or efficiency of $\mathrm{N}$ usage for milk production (Titgemeyer and Shirley, 1997; Reynal and Broderick, 2003). According to Ibarra et al. (2006), increasing the RUP concentration in RUP-deficient diets caused a re- 
duction in manure $\mathrm{N}$ excretion. There exists, therefore, the potential for RUP supplementation to increase the efficiency of $\mathrm{N}$ utilization and control manure $\mathrm{N}$ excretion by dairy cows.

Research has also shown that a dietary supply of readily fermentable carbohydrate improves the capture of ammonia in the rumen, thereby increasing microbial protein synthesis (Hristov and Jouany, 2005). Furthermore, when compared with starch or molasses, fermentable fiber from beet pulp enhanced the conversion of ruminal ammonia N into milk $\mathrm{N}$ (Hristov and Ropp, 2003). Therefore, with diets based on alfalfa silage, which contains a high proportion of RDP, beet pulp supplementation may stimulate microbial protein synthesis in the rumen and reduce $\mathrm{N}$ excretion to the environment.

The hypothesis underlying the experiment was that an increase in the efficiency of $\mathrm{N}$ utilization by lactating cows could be achieved by supplying RUP and decreasing the amount of RDP, or by increasing ruminal capture of RDP by partial replacement of starch with soluble fiber from beet pulp. The objectives of the study were to determine whether substitution of expeller SBM (a source of RUP) for solvent-extracted SBM (a source of RDP) or partial replacement of high-moisture shelled corn with beet pulp would be suitable strategies for improving lactation performance and efficiency of $\mathrm{N}$ usage by early lactating dairy cows. Our aim was to use solvent-extracted SBM as the reference treatment against which RUP supplementation and beet pulp substitution could be compared.

\section{MATERIALS AND METHODS}

\section{Animals and Treatments}

Eight multiparous Holstein cows, averaging $658 \pm 28$ $\mathrm{kg}$ of BW and $80 \pm 20 \mathrm{DIM}$, were used for the study. It was conducted according to a $4 \times 4$ double Latin square design, balanced for residual effects, with 21-d experimental periods (Cochran and Cox, 1957). Animal care procedures followed the guidelines of the Canadian Council on Animal Care (1993); the protocol was approved by the Institutional Animal Care Committee of the Dairy and Swine Research Centre in Sherbrooke, Quebec (Agriculture and Agri-Food Canada). Cows were maintained in tie stalls, and milked at 0900 and $2000 \mathrm{~h}$. The animals were fed ad libitum, twice daily (0800 and 1600) in amounts to ensure 10\% feed refusal. Water was freely available to all cows.

The TMR diets (Table 1) were formulated to be isocaloric, and were based on alfalfa silage (AS) and high-moisture shelled corn (HMSC). The dietary treat- ments were as follows: 1) the basal diet of AS and HMSC, without a protein supplement (diet NC; negative control); 2) diet NC supplemented with solventextracted SBM (ADM Agri-Industries, Windsor, ON, Canada; diet SSBM); 3) diet NC supplemented with expeller SBM (SoyPLUS, West Central, Ralston, IA; diet ESBM); 4) diet SSBM in which unmolassed dried beet pulp (Belisle Solution Nutrition, St. Mathias-surRichelieu, QC, Canada) replaced 50\% of the HMSC (diet SSBMBP).

\section{Sampling}

The total output of feces and urine was collected and weighed daily from d 17 to 21 . Representative samples $(2 \%)$ of excreta were collected and frozen immediately. Urine was collected in stainless steel containers; a Gooch tube (BF Goodrich Co., Kitchener, ON, Canada) was connected to the vulva of the cow and the tube was held in place with nylon netting glued to the rump with cement (Ag-Tek Division, Kane Enterprises, Sioux Falls, SD). Sulfuric acid $\left(\mathrm{H}_{2} \mathrm{SO}_{4}, 98 \% ; 10 \mathrm{~mL} / \mathrm{L}\right.$ of urine) was added to the urine containers to ensure that the $\mathrm{pH}$ of the urine was $<2.0$ (Spanghero and Kowalski, 1997). Feces were collected in preweighed plywood boxes lined with plastic. Orts were weighed daily. During the period of excreta collection, samples of individual feed ingredients, the TMR, and orts were obtained before the a.m. feeding and frozen $\left(-20^{\circ} \mathrm{C}\right)$ for subsequent analysis. All these samples except the orts were pooled by period. Milk yield was recorded from d 17 to 21, and samples from a.m. and p.m. milkings were collected and pooled daily according to milk production. Cows were weighed on 3 consecutive days (at $1000 \mathrm{~h}$ ), at the beginning of each period of the Latin square, and at the end of the last period.

On $d 21$, blood samples were obtained from the coccygeal vein, $1 \mathrm{~h}$ before and $3 \mathrm{~h}$ after the morning meal. The blood samples were collected into 2 evacuated tubes (one coated with sodium heparin, the other coated with EDTA). During blood collection, the samples were kept on ice, and then immediately centrifuged at 1,500 $\times$ $g$ for $12 \mathrm{~min}$. Plasma from the heparinized tubes was used to determine the concentrations of AA and urea N, whereas plasma from the EDTA-coated tubes was used for determination of NEFA. To analyze plasma AA, $0.2 \mathrm{~g}$ of an internal standard (a mixture of labeled AA; ${ }^{13} \mathrm{C}$ - and ${ }^{15} \mathrm{~N}$-labeled AA, CDN Isotopes, Pointe-Claire, QC, Canada; and Cambridge Isotope Laboratories Inc., Andover, MA) was added to $1 \mathrm{~g}$ of plasma (Raggio et al., 2004). This processed plasma sample was then frozen at $-80^{\circ} \mathrm{C}$; the remaining portion of unprocessed plasma was frozen at $-20^{\circ} \mathrm{C}$ for subsequent analysis. 
Table 1. Ingredient and nutrient composition of the experimental diets

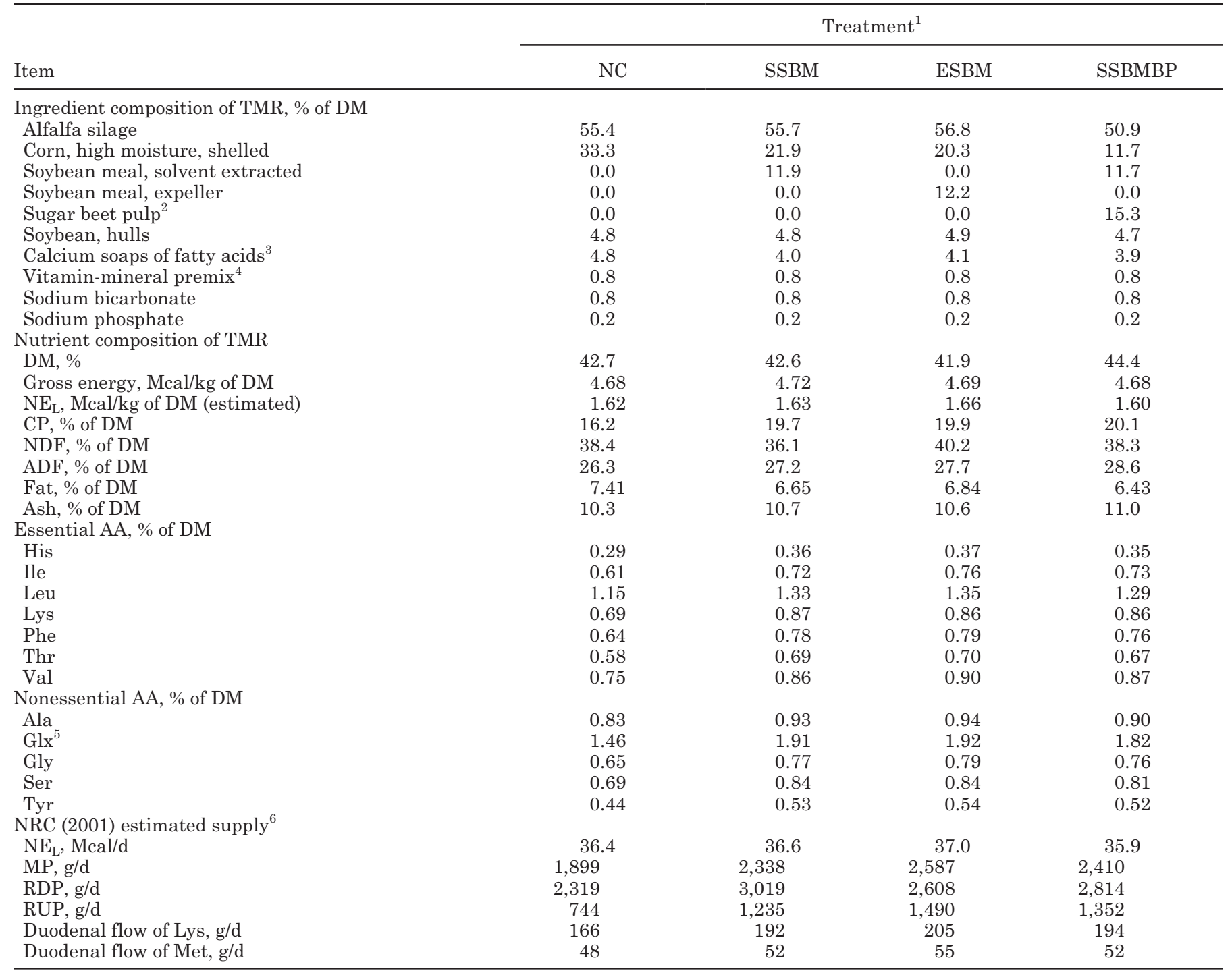

${ }^{1} \mathrm{NC}=$ alfalfa silage + high-moisture shelled corn; SSBM $=\mathrm{NC}+$ solvent-extracted soybean meal; ESBM = NC + expeller soybean meal; SSBMBP $=$ SSBM + sugar beet pulp.

${ }^{2}$ Unmolassed and dry, in pellets.

${ }^{3}$ Megalac (Church \& Dwight Co. Inc., Princeton, NJ).

${ }^{4}$ Commercial mix, Omni 0-0-13 (Shur Gain, Brossard QC, Canada): 18.9\% Na; 29\% Cl; 0.5\% Ca; 0.4\% P; $13 \% \mathrm{Mg} ; 4 \% \mathrm{~K} ; 5 \% \mathrm{~S} ; 6,200$ ppm Mn; 330 ppm Fe; 110 ppm Co; 193 ppm I; 1,500 ppm Cu; 7,000 ppm Z ; 46 ppm Se; 1,030,000 IU/kg of vitamin A; 182,000 IU/kg of vitamin D $4,320 \mathrm{IU} / \mathrm{kg}$ of vitamin $\mathrm{E}$.

${ }^{5} \mathrm{Glu}+\mathrm{Gln}$.

${ }^{6}$ Supply estimated for $22 \mathrm{~kg} / \mathrm{d}$ of DMI.

\section{Analytical Methods}

Samples of feed, orts, and feces were freeze-dried to determine DM content and were then ground to pass a 1-mm screen for subsequent chemical analysis. Ash and analytical DM were determined with a thermogravimetric analyzer (Model TGA-601, Leco Corporation, St. Joseph, MI). Analyses of NDF and ADF were performed (Ankom 200, Fiber Analyzer, Fairport, NY) according to the methods of Van Soest et al. (1991), using heat stable a-amylase (Ankom \#FAA, Macedon, NY), and without the addition of sodium sulfite. Fat content of the TMR was determined by gravimetric analysis, using ISCO SFX 3560 supercritical fluid extraction (ISCO Inc., Lincoln, NE) but without the use of cosolvent modifiers for extraction of phospholipids. Nitrogen was determined in all samples (except urine) by the combustion method using the Leco Nitrogen 
Determinator (model TruSpec v1.10, Leco). Urinary N was measured by micro-Kjeldahl analysis (Foss Tecator Kjeltec System, Brampton, ON, Canada). Urea N in urine, milk, and plasma was analyzed with a Technicon Analyzer (Technicon Instruments Corporation, Tarrytown, NY) based on colorimetric methods (Huntington, 1984; Reynolds et al., 1989). Energy content of samples of TMR, milk, feces, and urine was determined using an adiabatic bomb calorimeter (Parr Instruments Co., Moline, IL). Milk samples were analyzed for total solids using a thermo-gravimetric analyzer (model TGA 601, Leco), and milk fat was determined by the Röse-Gottlieb method (method 905.02; AOAC, 2000). Total N and protein- $\mathrm{N}$ in milk were measured by thermal conductivity (model TruSpec v1.10 Nitrogen Determinator, Leco) according to method 992.15 of AOAC (2000). The $\mathrm{N}$ concentrations were converted to $\mathrm{CP}$ concentrations using the factor 6.25 ; for milk protein, the conversion factor was 6.38 .

Concentrations of AA in individual feed ingredients and in the TMR were determined by the isotope dilution method of Calder et al. (1999). The feed samples were ground to pass a $0.5-\mathrm{mm}$ screen, then acid-hydrolyzed for $24 \mathrm{~h}$ at $110^{\circ} \mathrm{C}$ with $6 \mathrm{~N} \mathrm{HCl}$ to which phenol was added according to method 994.12 of AOAC (2000). A sample $(2 \mathrm{~g})$ of the hydrolysate was diluted with $3 \mathrm{~g}$ of ultra-pure water, and $1 \mathrm{~g}$ of this solution was combined with a mixture $(200 \mu \mathrm{g})$ of labeled AA, which served as an internal standard (Raggio et al., 2004). The mixture was then eluted through a poly-prep chromatography column (Resin 100-200 mesh H, Bio-Rad, Hercules, CA) and derivatized with $N$-(tert-butyldimethylsilyl)$N$ methyltrifluoroacetamide and dimethylformamide 1:1 (Sigma-Aldrich, St. Louis, MO) according to the method of Calder and Smith (1988). The AA were analyzed based on isotopic enrichment of each AA; quantification was achieved using GC-MS (Hewlett Packard model GC6890-MS973, Agilent Technologies Inc., Wilmington, DE). Performic acid oxidation of feed samples was not performed before acid hydrolysis. Therefore, neither Met nor Cys is reported; Trp was also not measured.

Purine derivatives (PD) and creatinine in acidified urine were determined by HPLC (System Gold HPLC, Beckman Instruments, Fullerton, CA), according to the procedure of Balcells et al. (1992). Concentration of NEFA was analyzed spectrophotometrically (Microplate Spectrophotometer System, Spectra Max 250, Molecular Devices, Sunnyvale, CA) with a commercial kit (NEFA-C, Wako Chemicals USA, Richmond, VA), using the method of McCutcheon and Bauman (1986). After being deproteinized with sulfosalicylic acid (38\%) and centrifuged $(27,768 \times g$ for $10 \mathrm{~min})$, plasma sam- ples were analyzed for AA using the isotopic dilution method described above.

\section{Calculations}

According to Sutter and Beever (2000), there is a fairly constant proportion of milk energy lost as heat; therefore, to obtain estimates of energy balance, heat loss associated with milk production was calculated using the equation of Sutter and Beever (2000); an estimate of heat production due to maintenance (NRC 2001; $\mathrm{NE}_{\mathrm{M}}=0.080 \mathrm{Mcal} / \mathrm{kg}$ of $\mathrm{BW}^{0.75}$ ) was then added to provide a value for total heat production. Methane energy losses were calculated using the linear equation of Mills et al. (2003) and converted to mega-calories per day:

$$
\text { Methane }(\mathrm{MJ} / \mathrm{d})=5.93+0.92(\mathrm{DMI} \mathrm{kg} / \mathrm{d}) \text {. }
$$

Energy balance (EB) was then calculated as:

$$
\mathrm{EB}=\mathrm{GEI}-(\mathrm{EF}+\mathrm{EU}+\mathrm{EM}+\mathrm{EH}+\mathrm{EMe}),
$$

where GEI = gross energy intake, EF = fecal energy, $\mathrm{EU}=$ urinary energy, $\mathrm{EM}=$ energy in milk, $\mathrm{EH}=$ heat energy, and EMe = energy lost as methane.

$\mathrm{N}$ balance was calculated as follows:

$$
\mathrm{N} \text { balance }=\mathrm{NI}-(\mathrm{NF}+\mathrm{UN}+\mathrm{NM}),
$$

where $\mathrm{NI}=$ nitrogen intake, $\mathrm{NF}=$ fecal $\mathrm{N}, \mathrm{UN}=$ urinary $\mathrm{N}$ and $\mathrm{NM}=\mathrm{N}$ excreted in milk.

\section{Statistical Analyses}

Data were analyzed using Proc Mixed of SAS (2001), with cow (random), period, and treatment (fixed) as main effects. A Latin square classification model was used to obtain estimates of least squares means for treatments. The following preplanned contrasts were undertaken: 1) NC vs. other treatments (SSBM, ESBM, and SSBMBP); 2) SSBM vs. ESBM; 3) SSBM vs. SSBMBP. The criterion for declaring an effect statistically significant was predetermined at the $5 \%$ probability level; values between the 5 and $10 \%$ levels of probability were considered as expressing a tendency.

The following statistical model was adopted:

$$
\mathrm{Y}_{\mathrm{ij}(\mathrm{k})}=\mu+\operatorname{Diet}_{\mathrm{i}}+\operatorname{Per}_{\mathrm{j}}+\operatorname{cow}_{(\mathrm{k})}+\mathrm{e}_{\mathrm{ij}(\mathrm{k})}
$$

where $Y_{\mathrm{ij}(\mathrm{k})}=$ value of the variable studied for the kth cow (1 to 8) receiving diet $i$ in period $j ; \mu=$ overall mean; Diet $_{\mathrm{i}}=$ the effect of the ith diet (NC, SSBM, ESBM, 
Table 2. Intake, digestibility, energy status, and performance of lactating dairy cows fed the experimental diets

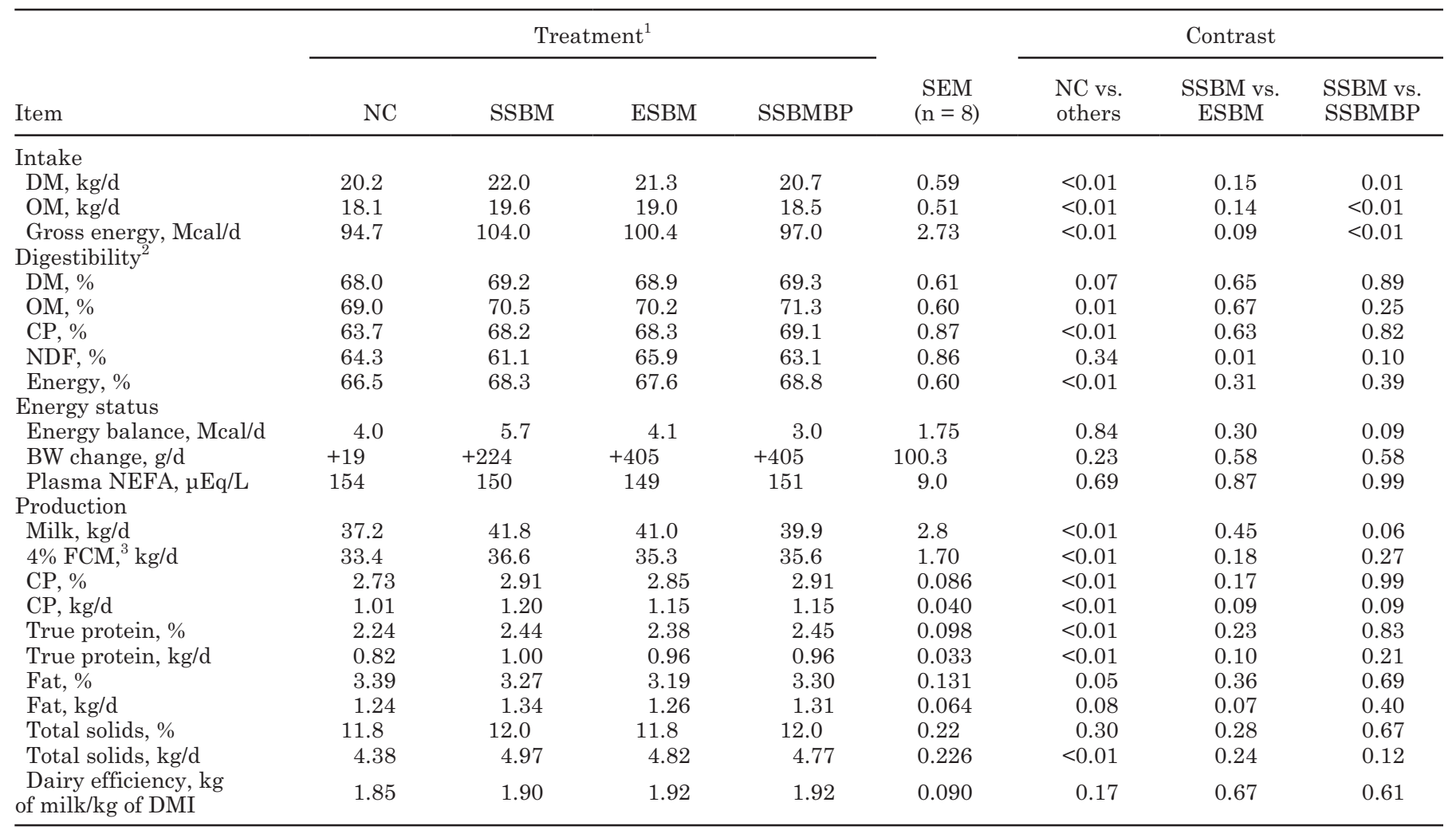

${ }^{1} \mathrm{NC}=$ alfalfa silage + high-moisture shelled corn; SSBM $=\mathrm{NC}+$ solvent-extracted soybean meal; ESBM = NC + expeller soybean meal; SSBMBP = SSBM + sugar beet pulp.

${ }^{2}$ Apparent digestibility in total tract, $\%$.

${ }^{3} 4 \% \mathrm{FCM}=[\mathrm{milk}(\mathrm{kg} / \mathrm{d}) \times 0.4]+[$ fat $(\mathrm{kg} / \mathrm{d}) \times 15) ;$ Gaines formula $(\mathrm{NRC}, 2001)$.

or SSBMBP); Per $_{j}=$ effect of the jth period $(1,2,3,4)$; $\operatorname{cow}_{(\mathrm{k})}=$ effect of the kth cow (1 to 8); $\mathrm{e}_{\mathrm{ij}(\mathrm{k})}=$ random error on the ijth measure on kth cow.

\section{RESULTS AND DISCUSSION}

\section{Intake, Digestibility, and Energy Status}

The alfalfa silage contained $19 \% \mathrm{CP}, 45 \% \mathrm{NDF}$, and $34 \% \mathrm{ADF}(\%$ of $\mathrm{DM})$. These values are typical of medium-quality alfalfa silage (NRC, 2001). The content of NPN and the $\mathrm{pH}$ of the alfalfa silage averaged $61.4 \%$ (of total $\mathrm{N}$ ) and 4.2 respectively, indicating that the silage was well preserved (Dulphy and Demarquilly, 1981). Table 1 shows the ingredient and nutrient composition of the experimental diets. Diet NC (negative control) contained the lowest concentrations of $\mathrm{CP}$ and AA. The diets were formulated based on an expected intake of $25 \mathrm{~kg} / \mathrm{d}$ (NRC 2001). Based on the NRC (2001) estimates of energy density $\left(\mathrm{NE}_{\mathrm{L}} / \mathrm{kg}\right.$ of $\left.\mathrm{DM}\right)$, the diets were isocaloric (Table 1). However, because of the lower intake of SSBMBP, this diet supplied less $\mathrm{NE}_{\mathrm{L}}$ than the others.
When compared with $\mathrm{NC}$, the protein-supplemented diets resulted in increases $(P<0.01)$ in DMI and OMI (Table 2). Digestibility of $\mathrm{OM}$ and energy increased with protein supplementation. This resulted in significant increases in digestible energy intake by cows receiving the protein-supplemented diets. That protein supplementation increased intake and digestibility of $\mathrm{OM}$ is not a unique observation. Previous research has shown that protein supplementation of alfalfa silage diets increases DMI by dairy cows (Grings et al., 1991; Dhiman and Satter, 1993). Van Soest (1994) and Kauffman and St-Pierre (2001) also reported increases in digestibility of $\mathrm{DM}$ and $\mathrm{OM}$ as the concentration of dietary $\mathrm{CP}$ increased. Improvements in intake of forage-based diets with protein supplementation can generally be attributed to improvements in fiber digestion, which alleviates rumen fill (Allen, 2000); however, in the present study there was no relationship between NDF digestion and intake.

The finding that RUP supplementation (SSBM vs. ESBM $)$ did not alter intake of DM and OM $(P>0.10)$ or digestibility of DM, OM, or gross energy $(P>0.10)$ is consistent with previous studies with lactating dairy 
cows (Reynal and Broderick, 2003; Ipharraguerre et al., 2005; Olmos Colmenero and Broderick, 2006b). In contrast to the observations reported here, Reynal and Broderick (2003) reported that dietary inclusion of expeller SBM reduced NDF digestibility by dairy cows. In the present study, NDF was analyzed without the use of sodium sulfite, whereas in the study by Reynal and Broderick (2003), sodium sulfite was used in the NDF procedure. This is an important distinction in NDF analysis because sodium sulfite reduces $\mathrm{N}$ residues in NDF (protein cross-links; Van Soest et al., 1991), which are present in expeller SBM (Borucki Castro et al., 2007). This could contribute to discrepancies in findings between our study and that of Reynal and Broderick (2003).

The rationale for partially replacing HMSC was to balance the ruminal release of $\mathrm{NH}_{3}-\mathrm{N}$ with a supply of highly fermentable carbohydrate such as that found in beet pulp (Robert et al., 1989). In vitro studies have shown that beet pulp supplementation reduces ruminal $\mathrm{NH}_{3}-\mathrm{N}$ concentrations (Bach et al., 1999; Hristov and Ropp, 2003) and prevents the negative effects of low ruminal $\mathrm{pH}$ (Voelker and Allen, 2003c). Results in Table 2 show that partial replacement of HMSC with beet pulp resulted in a reduction $(P<0.05)$ of $\mathrm{DM}$, $\mathrm{OM}$, and energy intakes without any effect on digestibility of DM, OM, or energy. Similar effects on intake have been observed with similar levels of beet pulp supplementation of diets for dairy cows (Mansfield et al., 1994; Voelker and Allen, 2003a). This effect of beet pulp may be related to distension of the reticulo-rumen (Allen, 2000). According to Bhatti and Firkins (1995), the functional specific gravity of beet pulp is low; this would result in a decrease in the rate of passage of diets containing beet pulp, thereby contributing to reticuloruminal distention. Compared with SSBM, SSBMBP tended to improve digestion of NDF, a finding that is consistent with results reported by Huhtanen (1988) and Voelker and Allen (2003b).

Estimates of energy balance and BW change (Table 2) were all positive, and the values for energy balance were similar to those reported in other studies with early lactating dairy cows (Holter et al., 1992; Tine et al., 2001). According to Sutter and Beever (2000), beyond wk 7 of lactation, the loss of BW ceases although negative energy balance may persist. In the present study, there were no effects $(P>0.10)$ of dietary treatment on energy balance or plasma concentrations of NEFA (Table 2). Replacing RDP with RUP has been shown to improve energy balance of dairy cows but the RUP-supplemented diets did result in 9\% greater intake of $\mathrm{NE}_{\mathrm{L}}$ (Santos et al., 1999). In the present study, energy intake tended to be greater with SSBM than with ESBM and this may explain the failure to observe an effect of RUP supplementation on energy balance. Supplementation with beet pulp (SSBMBP) also failed to alter energy balance (Table 2). According to de Visser et al. (1990), replacing corn or barley with beet pulp resulted in lower intake by dairy cows, and this caused increased mobilization of body fat and negative energy balance to sustain greater output of milk energy.

\section{Milk Yield and Composition and Plasma AA}

Supplying RUP (ESBM vs. SSBM) did not alter milk production or milk composition (Table 2); rather, it tended $(P<0.10)$ to reduce the yield of milk crude and true protein and milk fat. Based on NRC (2001) requirements for the secretion of $42 \mathrm{~kg} / \mathrm{d}$ of milk, SSBM did not supply enough RUP (-369 g/d). Therefore, providing RUP (from expeller SBM) was expected to improve RUP and MP balance, and increase milk production. Based on studies with early lactating dairy cows, supplying RUP from expeller SBM also failed to affect milk production (Reynal and Broderick, 2003; Leonardi et al., 2004). Titgemeyer and Shirley (1997) did observe a marginal (3\%) increase in milk production by providing RUP from expeller SBM but there was no response in milk protein yield. When compared with solvent-extracted SBM, expeller SBM has the potential to increase the RUP and intestinally available AA (Borucki Castro et al., 2007).

Concerns have been raised, however, about underestimation of RUP from solvent-extracted SBM based on observations of incomplete ruminal degradation of the soluble protein fraction of solvent-extracted SBM (Reynal et al., 2007). It is possible, therefore, that compared with diet SSBM, diet ESBM did not significantly increase the intestinal supply of Lys or Met; this would explain the lack of response to expeller SBM.

Table 3 shows the plasma concentrations of AA. The plasma concentrations of histidine, leucine, and valine were greater $(P \leq 0.05)$ with diet ESBM than with diet SSBM; plasma phenylalanine tended to be greater $(P$ $=0.08$ ) with ESBM than with SSBM, suggesting that the intestinal supply of essential AA (EAA) may have been greater with ESBM than with SSBM. However, plasma concentrations of Lys and Met (EAA that are often limiting) were similar $(P>0.10)$ for diets SSBM and ESBM. Bach et al. (2000) observed improvements in milk protein yield when the protein supplement was formulated with an EAA profile to match the EAA composition of casein. Noftsger and St-Pierre (2003) also reported improvements in milk production when RUP was supplied from animal by-products; the greatest response was recorded with diets fortified with methionine. It appears, therefore, that a positive response to RUP supplementation of diets for dairy cows is criti- 
Table 3. Concentrations of amino acids in plasma of lactating dairy cows fed the experimental diets

\begin{tabular}{|c|c|c|c|c|c|c|c|c|}
\hline Item & \multicolumn{4}{|c|}{ Dietary treatment $^{1}$} & $\begin{array}{c}\text { SEM } \\
(\mathrm{n}=8)\end{array}$ & \multicolumn{3}{|c|}{ Contrast } \\
\hline $\mathrm{His}$ & 18 & 43 & 52 & 53 & 4.0 & $<0.01$ & 0.05 & 0.03 \\
\hline Ile & 113 & 145 & 159 & 155 & 9.1 & $<0.01$ & 0.16 & 0.31 \\
\hline Leu & 135 & 163 & 185 & 161 & 10.4 & $<0.01$ & 0.04 & 0.80 \\
\hline Phe & 42 & 45 & 50 & 43 & 2.2 & 0.14 & 0.08 & 0.43 \\
\hline Thr & 88 & 102 & 90 & 98 & 6.4 & 0.16 & 0.14 & 0.59 \\
\hline Trp & 59 & 65 & 68 & 66 & 3.0 & $<0.01$ & 0.37 & 0.73 \\
\hline Val & 174 & 249 & 279 & 280 & 13.9 & $<0.01$ & 0.05 & 0.04 \\
\hline \multicolumn{9}{|c|}{ Nonessential AA, $\mu M$} \\
\hline Ala & 262 & 280 & 262 & 269 & 12.4 & 0.44 & 0.15 & 0.39 \\
\hline Gln & 292 & 290 & 271 & 267 & 13.2 & 0.28 & 0.29 & 0.21 \\
\hline
\end{tabular}

${ }^{1} \mathrm{NC}=$ alfalfa silage + high-moisture shelled corn; SSBM $=\mathrm{NC}+$ solvent-extracted soybean meal; ESBM = NC + expeller soybean meal; SSBMBP = SSBM + sugar beet pulp.

cally dependent on increasing the metabolic supply of those EAA that limit milk production. The fact that plasma concentrations of Met and Lys were not affected by substituting ESBM for SSBM may explain our failure to observe a response in milk production to RUP from ESBM.

Compared with SSBM, beet pulp supplementation (SSBMBP) increased $(P<0.05)$ plasma concentrations of histidine and valine (Table 3 ) but tended to reduce milk production and milk protein yield (Table 2); milk fat content was not affected. The decrease in milk yield was due to the lower $(P<0.10)$ DMI with SSBMBP compared with SSBM. Energy intake is a primary limitation on milk yield by high-producing dairy cows (Allen 2000); therefore, the lower level of milk production with beet pulp was due to lower energy intake. Research with beet pulp has produced equivocal results. In some studies, beet pulp supplementation has been shown to decrease milk yield (O'Mara et al., 1997) and milk protein content (Mansfield et al., 1994); in other studies, replacing corn with beet pulp had no effect on milk production (Friggens et al., 1995; Hristov and Ropp, 2003). According to Mansfield et al. (1994) and Voelker and Allen, (2003a), beet pulp supplementation increased milk fat content, whereas O'Mara et al. (1997) reported that beet pulp decreased milk fat content.

\section{Excretion of Purine Derivatives}

Urinary output of PD has been used to estimate microbial protein flow to the duodenum (Chen and Gomez,
1992), so it is important that estimates of urine output be reliable. Creatinine excretion is used to assess the reliability of urine collection (Valadares et al., 1999) and for this reason, it was analyzed and reported to validate estimates of PD excretion. The estimates for creatinine excretion in Table 4 range from 20 to $23 \mathrm{mg} /$ $\mathrm{kg}$ of BW per day and are within the range reported by other authors (Valadares et al., 1999), providing confidence in our estimates of PD excretion.

When compared with diet NC, diets SSBM, ESBM, and SSBMBP all resulted in greater excretion of PD (Table 4) and, potentially, greater outflows of microbial protein (Chen and Gomez, 1992). However, when compared with SSBM, neither beet pulp nor expeller SBM affected $(P>0.10)$ urinary excretion of PD. There are some reports of negative effects of RUP on ruminal microbial N (Santos et al., 1998; Ipharraguerre and Clark, 2005) but other studies have shown no effect on the duodenal flow of microbial $\mathrm{N}$ when expeller SBM was compared with solvent-extracted SBM (Reynal et al., 2003; Ipharraguerre et al., 2005). Beet pulp is thought to exert a positive effect on milk production by improving rumen function (Marounek and Dušková, 1999) and rumen microbial protein synthesis (Ben-Ghedalia et al., 1989), but Voelker and Allen (2003c) reported no effect of beet pulp on rumen microbial protein synthesis. Studies conducted in vitro (Hall and Herejk, 2001) and in vivo (Van Vuuren et al., 1993) have revealed lower efficiencies of rumen microbial protein synthesis when beet pulp replaced ingredients that supplied starch. It is quite likely that our failure to observe an effect of beet pulp, or RUP (ESBM), on milk production 
Table 4. Excretion of purine derivatives (PD) in lactating dairy cows fed the experimental diets

\begin{tabular}{|c|c|c|c|c|c|c|c|c|}
\hline Item & \multicolumn{4}{|c|}{ Dietary treatment ${ }^{1}$} & $\begin{array}{c}\text { SEM } \\
(\mathrm{n}=8)\end{array}$ & \multicolumn{3}{|c|}{ Contrast } \\
\hline Allantoin & 268 & 312 & 296 & 348 & 18.7 & 0.02 & 0.49 & 0.17 \\
\hline Uric acid & 46 & 52 & 50 & 52 & 3.2 & 0.05 & 0.70 & 0.84 \\
\hline
\end{tabular}

${ }^{1} \mathrm{NC}=$ alfalfa silage + high-moisture shelled corn; $\mathrm{SSBM}=\mathrm{NC}+$ solvent extracted soybean meal; ESBM = NC + expeller soybean meal; $\mathrm{SSBMBP}=\mathrm{SSBM}+$ sugar beet pulp.

was because of the lack of a net impact on intestinal supply of Met or Lys to cows fed diets containing these supplements.

\section{Nitrogen Balance and Efficiency}

Although there are limitations in absolute values for $\mathrm{N}$ balance (Spanghero and Kowalski, 1997), their utility lies in the fact that they can be used to assess relative differences among dietary treatments (Rand et al., 2003). Values for $\mathrm{N}$ balance (Table 5) were similar to those reported for mature dairy cows (Kauffman and St-Pierre, 2001; Wattiaux and Karg, 2004) but the estimates were not affected by treatment. The greater $(P$ $<0.01$ ) estimate for efficiency of $\mathrm{N}$ usage with the $\mathrm{NC}$ diet, as well as the lower values for plasma urea $\mathrm{N}$ and MUN $(P<0.05)$, were not unexpected; similar observations have been made previously (Kebreab et al., 2001; Olmos Colmenero and Broderick, 2006a).

Compared with the diet NC, the supplemented diets (SSBM, ESBM, SSBMBP) resulted in more $\mathrm{N}$ being secreted in milk $(P<0.01)$. According to $\mathrm{Wu}$ and Satter (2000) milk $\mathrm{N}$ secretion and the efficiency $\mathrm{N}$ usage would be optimized when a well-balanced diet contains
16.5\% CP. Diet NC (16.2\% CP) may not have contained enough $\mathrm{CP}$ to optimize milk $\mathrm{N}$ secretion. With the exception of MUN, all measures of $\mathrm{N}$ utilization were similar for the supplemented diets (Table 5). These findings are consistent with those of Olmos Colmenero and Broderick (2006b) who also observed no impact on efficiency of $\mathrm{N}$ usage for milk production when expeller SBM partly replaced solvent-extracted SBM. Noftsger and St-Pierre (2003) reported that the efficiency of $\mathrm{N}$ usage for milk production was increased when the EAA profile of RUP was improved or when dietary supply of methionine was increased. A report by Baker et al. (1995) also revealed that formulating the diet such that the EAA profile of the RUP matches that of milk protein results in greater efficiency of milk protein secretion. It seems that the lactation response to RUP requires that the supplemental RUP contain those EAA that are limiting for milk protein synthesis.

The rationale for partly replacing HMSC with beet pulp (SSBMBP) was to improve the capture of RDP in diet SSBM, thereby improving the utilization of dietary N. Beet pulp, which contains pectin, has been shown to improve rumen function when it replaces sources of starch (Marounek and Dušková, 1999). Table 5 reveals

Table 5. Nitrogen balance, urea concentrations and excretion in lactating dairy cows fed the experimental diets

\begin{tabular}{|c|c|c|c|c|c|c|c|c|}
\hline \multirow[b]{2}{*}{ Item } & \multicolumn{4}{|c|}{ Treatment $^{1}$} & \multirow[b]{2}{*}{$\begin{array}{l}\text { SEM } \\
(\mathrm{n}=8)\end{array}$} & \multicolumn{3}{|c|}{ Contrast } \\
\hline & $\mathrm{NC}$ & SSBM & ESBM & SSBMBP & & $\begin{array}{l}\text { NC vs. } \\
\text { others }\end{array}$ & $\begin{array}{l}\text { SSBM vs. } \\
\text { ESBM }\end{array}$ & $\begin{array}{l}\text { SSBM vs. } \\
\text { SSBMBP }\end{array}$ \\
\hline Fecal N, g/d & 189 & 216 & 215 & 207 & 6.8 & $<0.01$ & 0.82 & 0.14 \\
\hline Urinary $\mathrm{N}, \mathrm{g} / \mathrm{d}$ & 133 & 261 & 252 & 257 & 9.2 & $<0.01$ & 0.14 & 0.51 \\
\hline $\mathrm{N}$ balance, $\mathrm{g} / \mathrm{d}$ & 45 & 28 & 32 & 27 & 11.6 & 0.09 & 0.73 & 0.88 \\
\hline Urinary urea $N, g / d$ & 99 & 229 & 217 & 225 & 8.2 & $<0.01$ & 0.19 & 0.67 \\
\hline $\mathrm{PUN},{ }^{2} \mathrm{mg} / \mathrm{dL}$ & 9.2 & 17.2 & 16.5 & 15.9 & 0.87 & $<0.01$ & 0.37 & 0.11 \\
\hline MUN, mg/dL & 9.7 & 17.1 & 15.7 & 16.7 & 0.64 & $<0.01$ & 0.01 & 0.49 \\
\hline
\end{tabular}

${ }^{1} \mathrm{NC}=$ alfalfa silage + high-moisture shelled corn; $\mathrm{SSBM}=\mathrm{NC}+$ solvent-extracted soybean meal; ESBM = NC + expeller soybean meal; SSBMBP = SSBM + sugar beet pulp.

${ }^{2} \mathrm{PUN}=$ plasma urea nitrogen. 
that, compared with SSBM, diet SSBMBP failed to reduce $\mathrm{N}$ excretion or improve the efficiency of $\mathrm{N}$ usage for milk production. This may have been because beet pulp did not alter rumen microbial protein synthesis (Table 4). Results in Table 5 do indicate a tendency for plasma urea $\mathrm{N}$ concentration to be less with beet pulp supplementation than with SSBM; this would suggest that beet pulp may, indeed, have improved the efficiency of $\mathrm{N}$ usage. The apparent inconsistency between the response in plasma urea $\mathrm{N}$ and other measures of $\mathrm{N}$ utilization suggests that more sensitive measures of $\mathrm{N}$ metabolism may be required to assess the impact of beet pulp supplementation for dairy cows.

\section{CONCLUSIONS}

Replacing solvent-extracted SBM with expeller SBM to supply a greater amount of RUP did not improve lactation performance or efficiency of $\mathrm{N}$ usage in dairy cows fed diets based on alfalfa silage. Partial substitution of beet pulp (to supply fermentable fiber) for high-moisture shelled corn (a source of starch) had no effect on rumen microbial protein synthesis or lactation performance. Compared with diet SSBM, beet pulp supplementation decreased DMI and this tended to reduce milk production. Failure to observe an effect of either expeller SBM or beet pulp on milk production or efficiency of $\mathrm{N}$ utilization may have been due to the lack of a net improvement in the intestinal supply of Met or Lys.

\section{ACKNOWLEDGMENTS}

The authors wish to thank Sylvie Provencher and Lisa Croteau for technical support, Jocelyne Renaud for AA analyses, and Steve Methot for statistical advice and management of data. The assistance of the dairy barn staff from Lennoxville Research Centre is also appreciated. Financial support from West Central (Ralston, IA) and Agriculture and Agri-Food Canada is gratefully acknowledged. Dairy and Swine Research and Development Center contribution number 964.

\section{REFERENCES}

Allen, M. S. 2000. Effects of diet on short-term regulation of feed intake by lactating dairy cows. J. Dairy Sci. 83:1598-1624.

AOAC. 2000. Official Methods of Analysis. 17th ed. AOAC, Arlington, VA.

Bach, A., G. B. Huntington, S. Calsamiglia, and M. D. Stern. 2000. Nitrogen metabolism of early lactation cows fed diets with two different levels of protein and different amino acid profiles. J. Dairy Sci. 83:2585-2595.

Bach, A., I. K. Yoon, M. D. Stern, H. G. Jung, and H. Chester-Jones. 1999. Effects of type of carbohydrate supplementation to lush pasture on microbial fermentation in continuous culture. J. Dairy Sci. 82:153-160.
Baker, L. D., J. D. Ferguson, and W. Chalupa. 1995. Responses in urea and true protein of milk to different protein feeding schemes for dairy cows. J. Dairy Sci. 78:2424-2434.

Balcells, J., J. A. Guada, J. M. Peiro, and D. S. Parker. 1992 Simultaneous determination of allantoin and oxypurines in biological fluids by high-performance liquid chromatography. J. Chromatogr. 575:153-157.

Ben-Ghedalia, D., E. Yosef, J. Miron, and Y. Est. 1989. The effects of starch and pectin-rich diets on quantitative aspects of digestion in sheep. Anim. Feed Sci. Technol. 24:289-298.

Bhatti, S. A., and J. L. Firkins. 1995. Kinetic of hydration and functional specific gravity of fibrous feed by-products. J. Anim. Sci. 73:1449-1458.

Børsting, C. F., T. Kristensen, L. Misciattelli, T. Hvelplund, and M. R. Weisbjerg. 2003. Reducing nitrogen surplus from dairy farms. Effects of feeding and management. Livest. Prod. Sci. 83:165178.

Borucki Castro, S. I., L. E. Phillip, H. Lapierre, P. W. Jardon, and R. Berthiaume. 2007. Ruminal degradability and intestinal digestibility of protein and amino acids in treated soybean meal products. J. Dairy Sci. 90:810-822.

Calder, A. G., K. E. Garden, S. E. Anderson, and G. E. Lobley. 1999 Quantification of blood and plasma amino acids using isotope dilution electron impact gas chromatography/mass spectrometry with U-13C amino acids as internal standard. Rapid Commun. Mass Spectrom. 13:2080-2083.

Calder, A. G., and A. Smith. 1988. Stable isotope ratio analysis of leucine and ketoisocaproic acid in blood plasma by gas chromatography mass spectrometry. Use of tertiary butyldimethylsilyl derivatives. Mass Spectrom. 2:14-16.

Canadian Council on Animal Care. 1993. Guidelines for the Care and Use of Experimental Animals. Vol. I. 2nd ed. E. D. Olfert, B. M. Cross and A. A. McWilliam, ed. CCAC, Ottawa, Ontario, Canada.

Chen, X. B., and M. J. Gomes. 1992. Estimation of microbial protein supply to sheep and cattle based on urinary excretion of purine derivatives-An overview of the technical details. Pages 1-21 in Occ. Publ. Int. Feed Resources Unit, Rowett Research Institute, Bucksburn, Aberdeen, UK.

Cochran, W. G., and G. M. Cox. 1957. Completely randomized, randomized block, and Latin square designs. Chapter 4 in Experimental Designs. 2nd ed. J. Wiley \& Sons, Inc., New York, NY.

de Visser, H., P. L. van der Togt, and S. Tamminga. 1990. Structural and non-structural carbohydrates in concentrate supplements of silage-based dairy cows rations. 1. Feed intake and milk production. Neth. J. Agric. Sci. 38:487-498.

Dhiman, T. R., and L. D. Satter. 1993. Protein as the first-limiting nutrient for lactating dairy cows fed high proportions of good quality alfalfa silage. J. Dairy Sci. 76:1960-1971.

Dulphy, J. P., and C. Demarquilly. 1981. Problèmes particuliers aux ensilages. Pages 81-104 in Prévision de la valeur nutritive des aliments des ruminants. INRA, Paris, France.

Friggens, N., G. C. Emmans, S. Robertson, D. G. Chamberlain, C. T. Whittemore, and J. D. Oldham. 1995. The lactational responses of dairy cows to amount of feed and to the source of carbohydrate energy. J. Dairy Sci. 78:1734-1744.

Grings, E. E., R. E. Roffler, and D. P. Deitelhoff. 1991. Response of dairy cows in early lactation to additions of cottonseed meal in alfalfa-based diets. J. Dairy Sci. 74:2580-2587.

Hall, M. B., and C. Herejk. 2001. Differences in yields of microbial crude protein from in vitro fermentation of carbohydrates. J. Dairy Sci. 84:2486-2493.

Holter, J. B., H. H. Hayes, W. E. Urban Jr., and A. H. Duthie. 1992. Energy balance and lactation response in Holstein cows supplemented with cottonseed with or without calcium soap. J. Dairy Sci. 75:1480-1494.

Hristov, A. N., and J. P. Jouany. 2005. Factors affecting the efficiency of nitrogen utilization in the rumen. Pages 117-150 in Nitrogen and Phosphorus Nutrition of Cattle. A. Hristov and E. Pfeffer, ed. CABI Publishing, Wallingford, UK. 
Hristov, A. N., and J. K. Ropp. 2003. Effect of dietary carbohydrate composition and availability on utilization of ruminal ammonia nitrogen for milk protein synthesis in dairy cows. J. Dairy Sci. 86:2416-2427.

Huhtanen, P. 1988. The effects of barley, unmolassed sugar beet pulp and molasses supplements on organic matter, nitrogen and fibre digestion in the rumen of cattle given a silage diet. Anim. Feed Sci. Technol. 20:259-278.

Huntington, G. B. 1984. Net absorption of glucose and nitrogenous compounds by lactating Holstein cows. J. Dairy Sci. 67:19191927.

Ibarra, D., L. Latrille, and F. Wittwer. 2006. Incremento en la proteína no degradable en rumen de vacas lecheras: 2. Efectos sobre utilización y excreción del nitrógeno. Arch. Med. Vet. 38:219-225.

Ipharraguerre, I. R., and J. H. Clark. 2005. Impacts of the source and amount of crude protein on the intestinal supply of nitrogen fractions and performance of dairy cows. J. Dairy Sci. 88(E Suppl.):E22-E37.

Ipharraguerre, I. R., J. H. Clark, and D. E. Freeman. 2005. Rumen fermentation and intestinal supply of nutrients in dairy cows fed rumen-protected soy products. J. Dairy Sci. 88:2879-2892.

Kauffman, A. J., and N. R. St-Pierre. 2001. The relationship of milk urea nitrogen to urine nitrogen excretion in Holstein and Jersey cows. J. Dairy Sci. 84:2284-2294.

Kebreab, E., J. France, D. E. Beever, and A. R. Castillo. 2001. Nitrogen pollution by dairy cows and its mitigation by dietary manipulation. Nutr. Cycl. Agroecosyst. 60:275-285.

Kellogg, R. L., C. H. Lander, D. C. Moffitt, and N. Gollehon. 2000. Manure Nutrients Relative to the Capacity of Cropland and Pastureland to Assimilate Nutrients: Spatial and Temporal Trends for the United States. Publ. nps 00-0579. USDA-NRCS Economic Research Service. Online: http://www.nrcs.usda.gov/ technical/land/pubs/manntr.pdf

Leonardi, C., W. Stockland, and L. E. Armentano. 2004. Production response of dairy cows fed soybean meal heat-treated with different methodologies. Prof. Anim. Sci. 20:74-78.

MacRae, T., and C. A. S. Smith. 2000. Report of Agric. Environmental Indicator Project: A Summary. In: Environmental sustainability of Canadian agriculture. T. McRae, C. A. S. Smith, and L. J. Gregorich, ed. Online: http://www.agr.ca/policy/environment/

Mansfield, H. R., M. D. Stern, and D. E. Otterby. 1994. Effects of beet pulp and animal by-products on milk yield and in vitro fermentation by rumen microorganisms. J. Dairy Sci. 77:205216.

Marounek, M., and D. Dušková. 1999. Metabolism of pectin in rumen bacteria Butyrivibrio fibrisolvens and Prevotella ruminicola. Lett. Appl. Microbiol. 29:429-433.

McCutcheon, S. N., and D. E. Bauman. 1986. Effect of chronic growth hormone treatment on responses to epinephrine and thyrotropinreleasing hormone in lactating cows. J. Dairy Sci. 69:44-51.

Mills, J. A. N., E. Kebreab, C. M. Yates, L. A. Crompton, S. B. Cammell, M. S. Dhanoa, R. E. Agnew, and J. Frances. 2003. Alternative approaches to predicting methane emissions from dairy cows. J. Anim. Sci. 81:3141-3150.

Noftsger, S., and N. R. St-Pierre. 2003. Supplementation of methionine and selection of highly digestible rumen undegradable protein to improve nitrogen efficiency from milk production. J. Dairy Sci. 86:958-969.

NRC. 2001. Nutrient Requirements of Dairy Cattle. 7th rev. ed. Natl. Acad. Press, Washington, DC.

O’Mara, F. P., G. K. Stakelum, P. Dillon, J. J. Murphy, and M. Rath. 1997. Rumen fermentation and nutrient flows for cows fed grass and grass supplemented with molassed beet pulp pellets. J. Dairy Sci. 80:2466-2474.

Olmos Colmenero, J. J., and G. A. Broderick. 2006a. Effect of dietary crude protein concentration on milk production and nitrogen utilization in lactating dairy cows. J. Dairy Sci. 89:1704-1712.

Olmos Colmenero, J. J., and G. A. Broderick. 2006b. Effect of amount and ruminal degradability of soybean meal protein on performance of lactating dairy cows. J. Dairy Sci. 89:1635-1643.
Raggio, G., D. Pacheco, R. Berthiaume, G. E. Lobley, D. Pellerin, G. Allard, P. Dubreuil, and H. Lapierre. 2004. Effect of level of metabolizable protein on splachnic flux of amino acids in lactating cows. J. Dairy Sci. 87:3461-3472.

Rand, W. M., P. L. Pellett, and V. R. Young. 2003. Meta-analysis of $\mathrm{N}$ balance studies for estimating protein requirements in healthy adults. Am. J. Nutr. 77:109-127.

Reynal, S. M., and G. A. Broderick. 2003. Effects of feeding dairy cows protein supplements of varying ruminal degradability. J. Dairy Sci. 86:835-843.

Reynal, S. M., G. A. Broderick, S. Ahvenjarvi, and P. Huhtanen. 2003. Effect of feeding protein supplements of differing degradability on omasal flow of microbial and undegraded protein. J. Dairy Sci. 86:1292-1305.

Reynal, S. M., I. R. Ipharraguerre, M. Liñeiro, A. F. Brito, G. A. Broderick, and J. H. Clark. 2007. Omasal flow of soluble proteins, peptides, and free amino acids in dairy cows fed diets supplemented with proteins of varying ruminal degradabilities. J. Dairy Sci. 90:1887-1903.

Reynolds, C. K., G. B. Huntington, T. H. Elsasser, H. F. Tyrrell, and P. J. Reynolds. 1989. Net metabolism of hormones by portaldrained viscera and liver of lactating Holstein cows. J. Dairy Sci. 72:1459-1468.

Robert, P., C. Bertin, and D. Bertrand. 1989. Rumen microbial degradation of beet root pulps. Application of infrared spectroscopy to the study of protein and pectin. J. Agric. Food Chem. 37:624-627.

Santos, F. A. P., J. E. P. Santos, C. B. Theurer, and J. T. Huber. 1998. Effects of rumen-undegradable protein on dairy cows performance: A 12-year literature review. J. Dairy Sci. 81:31823213.

Santos, J. E. P., J. T. Huber, C. B. Theurer, L. G. Nussio, M. Tarazon, and F. A. P. Santos. 1999. Response of lactating dairy cows to steam-flaked sorghum, steam-flaked corn, or steam-rolled corn and protein sources of differing degradability. J. Dairy Sci. 82:728-737.

SAS Institute. 2001. SAS System for Windows Release 8.2 (TS2M0). SAS Institute Inc., Cary, NC.

Spanghero, M., and Z. M. Kowalski. 1997. Critical analysis of N balance experiments with lactating cows. Livest. Prod. Sci. $52: 113-122$

Sutter, F., and D. E. Beever. 2000. Energy and nitrogen metabolism in Holstein-Friesian cows during early lactation. Anim. Sci. 70:503-514.

Tine, M. A., K. R. Mcleod, R. A. Erdman, and R. L. Baldwin VI. 2001. Effects of brown midrib corn silage on the energy balance of dairy cattle. J. Dairy Sci. 84:885-895.

Titgemeyer, E. C., and J. E. Shirley. 1997. Effect of processed grain sorghum and expeller soybean meal on performance of lactating cows. J. Dairy Sci. 80:714-721.

Valadares, R. F. D., G. A. Broderick, S. C. Valadares Filho, and M. K. Clayton. 1999. Effect of replacing alfalfa silage with high moisture corn on ruminal protein synthesis estimated from excretion of total purine derivatives. J. Dairy Sci. 82:2686-2696.

Van Soest, P. J. 1994. Nitrogen Metabolism. Pages 290-311 in Nutritional Ecology of the Ruminant. Cornell University Press, Ithaca, NY.

Van Soest, P. J., J. B. Robertson, and B. A. Lewis. 1991. Methods for dietary fiber, neutral detergent fibre, and non-starch polysaccharides in relation to animal nutrition. J. Dairy Sci. 74:3583-3597.

Van Vuuren, A. M., C. J. van der Koelen, and J. Vroons-de Bruin. 1993. Ryegrass versus corn starch or beet pulp fiber diet effects on digestion and intestinal amino acids in dairy cows. J. Dairy Sci. 76:2692-2700.

Vandehaar, M. J., and N. St-Pierre. 2006. Major advances in nutrition: Relevance to the sustainability of the dairy industry. J. Dairy Sci. 89:1280-1291.

Voelker, J. A., and M. S. Allen. 2003a. Pelleted beet pulp substituted for high-moisture corn: 1. Effects on feed intake, chewing 
behaviour, and milk production of lactating dairy cows. J. Dairy Sci. 86:3542-3552.

Voelker, J. A., and M. S. Allen. 2003b. Pelleted beet pulp substituted for high-moisture corn: 2. Effects on digestion and ruminal digestion kinetics in lactating dairy cows. J. Dairy Sci. 86:35533561.

Voelker, J. A., and M. S. Allen. 2003c. Pelleted beet pulp substituted for high-moisture corn: 3. Effects on ruminal fermentation, $\mathrm{pH}$, and microbial protein efficiency in lactating dairy cows. J. Dairy Sci. 86:3562-3570.

Wattiaux, M. A., and K. L. Karg. 2004. Protein level for alfalfa and corn silage-based diets: II. Nitrogen balance and manure characteristics. J. Dairy Sci. 87:3492-3502.

Wu, Z., and L. D. Satter. 2000. Milk production during the complete lactation of dairy cows fed diets containing different amounts of protein. J. Dairy Sci. 83:1042-1051. 